\title{
Perbandingan Tepung Ketan dan Labu Siam (Sechium Edule) Terhadap Karakteristik Dodol
}

\author{
I Gede Arisudana, Anak Agung Made Semariyani, I Putu Candra, Luh Suriati \\ Program Studi Ilmu dan Teknologi Pangan, Fakultas Pertanian, Universitas Warmadewa \\ E-mail: arisudana22081988@gmail.com
}

\begin{abstract}
This study aims to determine the effect of the ratio of glutinous rice flour and the squash to the resulting dodol characteristics, and to obtain the appropriate ratio of glutinous flour and pistachio to produce dodol with good characteristics and acceptable to consumers. This study used Randomized Block Design (RBD) with 6 (six) comparative treatments namely: T0 (100\% glutinous flour: $0 \%$ squash); T1 (80\% glutinous flour: $20 \%$ squash): T2 (70\% glutinous flour: 30\% squash); T3 (60\% glutinous flour: $40 \%$ squash); T4 (50\% glutinous flour: $50 \%$ squash and T5 (40\% glutinous flour and 60\% squash) Each treatment was repeated 3 times to obtain 18 units of experiments. Based on the results, it can be concluded that the ratio of glutinous flour and gourd flakes have significant effect on water content, ash content, crude fiber content, $\mathrm{pH}$, total sugar, texture, aroma, flavor and overall acceptance of dodol squash. The ratio of $70 \%$ starch flour and 30\% pumpkin yields a good dodol of cauliflower and not significantly different from the control (100\% glutinous flour: $0 \%$ squash). Characteristic dodol pumpkin with a ratio of $70 \%$ glutinous flour: $30 \%$ squash is as follows: water content $19.774 \%$, ash $0.763 \%$, crude fiber $0.925 \%$, pH 6.270, total sugar 14.660 brix, 4.286 (chewy, elastic, non-breakable) texture taste, 3.000 aroma (somewhat typical dodol squash), 4.286 (sweet legit) flavor, overall acceptance 5.714 (likes) and all these characteristics meet per the requirement of SNI dodol (SNI 01-2986-1992).
\end{abstract}

Keywords: dodol, glutinous flour, squash

\section{Pendahuluan}

Dodol merupakan makanan tradisional yang sangat terkenal sejak zaman dahulu dan banyak dijumpai di pasaran. Dodol biasanya dimakan sebagai makanan selingan. Dodol memiliki rasa manis, gurih, berwarna coklat, tekstur lunak, digolongkan makanan semi basah (Prayitno,2002). Dodol untuk masing-masing daerah memiliki nama khas, dodol Garut berasal dari Garut dan dodol Kudus berasal dari Kudus, dengan bahan dasar tepung ketan. Dodol dapat dibuat atau dicampurkan dengan bahan tambahan seperti buah-buahan ataupun sayuran seperti buah apel, nangka, salak, labu kuning, labu siam dan sebagainya.

Labu siam (Sechium edule) adalah tumbuhan suku labu-labuan (Cucurbitaceae) yang dapat dimakan buah dan pucuk mudanya. Tumbuhan ini merambat di tanah atau agak memanjat dan biasa dibudidayakan di pekaranagan, dan juga di dekat kolam. Buah menggantung dari tangkai. Daunnya berbentuk mirip segitiga dan permukaannya berbulu. Di Indonesia, labu siam merupakan sayuran yang hampir selalu dapat dijumpai di pasar.

Labu siam (Sechium edule) merupakan sayuran yang mengandung banyak nutrisi dan vitamin yang sangat berguna bagi tubuh manusia. Labu siam mengandung senyawa-senyawa yang berpotensi sebagai antioksidan, maka labu siam juga dapat menjadi sumber antioksidan alami. Menurut Saade, 1996; Modgil et al.,2004, dalam 100 gram daging buah labu siam mengandung 26-31 kkal, protein 0,9-1,1\%, serat $0,4-1 \%$, flavonoid 0,95\%, kalsium $12-19 \mathrm{mg}$, vitamin A $5 \mathrm{mg}$, dan masih banyak lagi kandungan lainnya yang dapat bermanfaat bagi tubuh manusia. Olahan labu siam yang sudah umum dibuat oleh masyarakat antara lain dalam bentuk sayuran, manisan, sirup, jelly dan selai, perlu ada inovasi untuk membuat harga jual labu siam menjadi meningkat, salah satu caranya yaitu dengan membuat suatu 
produk dari labu siam yang menarik untuk dikonsumsi yaitu berupa dodol, selain populer juga merupakan jenis makanan yang digemari oleh mayoritas masyarakat Indonesia dengan memberikan rasa yang berbeda, aroma yang khas, tekstur tetap sesuai karakteristik produk standar, serta diterima di kalangan masyarakat.

Dodol labu siam menjadi salah satu alternatif baru sebagai olahan makanan yang aman dan menyehatkan, karena dodol labu siam tidak mengandung lemak jenuh atau kolesterol, dan tidak mengandung bahan tambahan makanan yang berbahaya. Jadi selain tampilannya cantik dan banyak khasiat dodol labu siam sangat aman dikonsumsi oleh segala golongan dan lapisan masyarakat, namun belum diketahui komposisi yang tepat dalam proses pembuatannya.

Berdasarkan hal tersebut di atas maka perlu dilakukan penelitian mengenai perbandingan tepung ketan dan labu siam (Sechium edule) untuk memperoleh dodol labu siam dengan karakteristik yang baik serta disukai atau diterima oleh konsumen.

\section{Bahan dan Metode}

\subsection{Tempat, Waktu, Bahan, dan Alat Penelitian}

Penelitian ini dilakukan di Laboratorium Pengolahan Hasil Pertanian, Fakultas Pertanian, Universitas Warmadewa mulai bulan Mei - Juli 2017.

Bahan yang digunakan dalam penelitian ini adalah labu siam, santan, pewarna makanan, air, tepung ketan, tepung beras, gula pasir. Bahan kimia yang digunakan adalah aquades, $\mathrm{H}_{2} \mathrm{SO}_{4}, \mathrm{NaOH}$, Alkohol, $\mathrm{HCL}, \mathrm{Na}_{2} \mathrm{SO}_{3}, \mathrm{Kl}$, aquadest .

Alat yang digunakan dalam penelitian ini secara umum dibagi menajadi 2 bagian yaitu: (1) Peralatan untuk membuat produk dalam hal ini adalah dodol, yaitu: panci, kompor, blender, gelas ukur, timbangan, saringan, pengaduk, wajan. (2) Peralatan yang digunakan saat analisa yaitu: timbangan analitik (adventure Tm. Ohaus AR 2140), cawan, kompor listrik, penangas air, kertas saring, labu ukur $10 \mathrm{ml}$ dan $100 \mathrm{ml}$, corong, baeker glass, pinset, aluminium foil, tissue, pipet mikro, erlenmeyer $600 \mathrm{ml}$, termometer, kertas label, $\mathrm{pH}$ meter.

\subsection{Rancangan Percobaan}

Penelitian ini menggunakan Rancangan Acak Kelompok (RAK) dengan 6 perlakuan perbandingan tepung beras ketan dan labu siam, yaitu: $100 \%$ tepung ketan: $0 \%$ labu siam (T0 = Kontrol), 80\% tepung ketan: 20\% labu siam (T1), 70\% tepung ketan: 30\% labu siam (T2), 60\% tepung ketan: 40\% labu siam (T3), 50\% tepung ketan: 50\% labu siam (T4), 40\% tepung ketan: 60\% labu siam (T5)

Seluruh perlakuan diulang 3 kali sehingga diperoleh 18 unit percobaan.Data yang diperoleh dari percobaan dianalisis dengan analisis sidik ragam dan apabila perlakuan berpengaruh nyata atau sangat nyata maka dilanjutkan dengan Uji BNT..

\subsection{Proses Pembuatan Dodol Labu Siam}

Pelaksanaan penelitian diawali dengan tahap persiapan. Pada tahap persiapan, langkah pertama yang 
dilakukan adalah bahan yang diperlukan disortasi terlebih dahulu dengan memilih labu siam yang masih utuh, tidak memar dan busuk, kemudian labu siam dikupas dan dipotong sesuai ukuran. Setelah itu labu siam yang telah dibersihkan, dikukus sampai matang. Labu siam yang telah matang, dihancurkan dengan menggunakan blender. Setelah labu siam tersebut diblender maka langkah selanjutnya adalah menimbang bubur labu siam, tepung ketan, tepung beras, gula, sesuai dengan perlakuan.

Langkah selanjutnya adalah menyiapkan santan kental dan santan encer masing-masing sebanyak $500 \mathrm{ml}$. Kemudian santan kental dituangkan ke dalam wajan dan dipanaskan dengan menggunakan kompor dengan api sedang. Setelah itu masukkan gula pasir sebanyak 700 gram, dan diaduk hingga merata. Sementara menunggu adonan mendidih, tepung ketan, tepung beras, bubur labu siam dan santan encer dicampur sesuai perlakuan kemudian diaduk hingga merata. Setelah adonan mendidih, masukkan campuran tepung, bubur labu siam dan santan encer yang sudah di siapkan secara perlahan-lahan sambil adonan tersebut diaduk.

Adonan yang telah dicampur, kemudian diaduk hingga tercampur sempurna dan menjadi kalis. Kemudian campurkan pewarna makanan sesuai selera secukupnya, dan aduk hingga matang $( \pm 90$ menit). Dodol yang sudah matang dituangkan dalam cetakan yang sudah disiapkan kemudian didinginkan selama satu malam. Setelah dingin dodol dipotong sesuai ukuran yang diinginkan, dan dibungkus dengan menggunakan plastik. Dodol labu siam siap di analisa.

\subsection{Pengamatan dan Analisis}

\section{Analisis Kadar Air}

Meurut Sudarmadji, dkk (1984) penentuan kadar air dapat dilakukan dengan cara pemanasan (AOC, 1970) dengan cara kerja sebagai berikut: bahan ditimbang sebnyak 1-2 gram dalam botol timbang yang telah diketahui beratnya, kemudian dikeringkan dalam oven pada suhu $100-105^{\circ} \mathrm{C}$ selama $3-5$ jam tergantung bahannya. Kemudian didinginkan dalam desikator dan timbang. Panaskan lagi dalam oven selama 30 menit, dinginkan dalam desikator dan timbang, perlakuan ini dilakukan sampai mencapai berat konstan (selisih penimbangan berturut-turut kurang dari 0,2 $\mathrm{mg}$ ). Pengurangan berat merupakan banyaknya air dalam bahan.

\section{Analisis Kadar Abu}

Menurut Sudarmadji, dkk. (1996) kadar abu ditetapkan dalam cara kering. Adapun penetapan kadar abu dapat dilakukan sebagai berikut: Sampel bebas lemak dikeringkan pada suhu $100-105^{\circ} \mathrm{C}$ sampai berat konstan, kemudian dibakar sampai sampel menjadi arang.Kemudian sampel ditimbang seberat 1-2 gr, diletakkan dalam krush dari porselin, kemudian dimasukan dalam muffle, dengan suhu $525^{\circ} \mathrm{C}$. pengabuan dilakukan sampai sisa pengabuan berwarna keputihan dan beratnya konstan dengan selang waktu pengabuan 30 menit. Hasil pengabuan diletakkan dalam oven samai suhu mencapai $105^{\circ} \mathrm{C}$, kemudian diletakkan dalam desikator dan ditimbang.

\section{Analisis Serat Kasar}

Menurut Sudarmadji dkk. (1997), untuk pengujian serat kasar dapat dilakukan dengan cara: Bahan dihaluskan sehingga dapat melalui ayakan dengan ukuran diameter $1 \mathrm{~mm}$ dan dicampur dengan baik. Jika bahan tidak dapat dihaluskan, sedapat mungkin bahan dihancurkan.Bahan kering ditimbang sebanyak 2 
gram dan ekstraksi lemak dengan soxhlet. Bahan dipindahkan ke dalam erlemeyer $600 \mathrm{ml}$ dan ditambah 200ml larutan 0,255 $\mathrm{N} \mathrm{H}_{2} \mathrm{SO}_{4}$ yang telah didihkan dan tutuplah dengan pendingin, lalu didihkan selama 30 menit dengan digoyang-goyangkan. Suspense kemudian disaring melalui kertas saring dan residu yang tertinggal dalam erlemyer dicuci denga aquadest yang telah didihkan.Residu dalam kertas saring dicuci sampai air cucian tidak bersifat asam lagi (diuji dalam kertas lakmus). Residu dari kertas saring dipindahkan secara kuantitatif ke dalam ermeyer kembali dengan spatula dan sisanya dicuci dengan larutan $0.313 \mathrm{~N} \mathrm{NaOH}$ mendidih sebanyak $200 \mathrm{ml}$ sampai semua residu masuk ke dalam erlemeyer. Hasilnya didihkan dengan pendingin sambil digoyang-goyang selama 30 menit dan disaring melalui kertas saring kering yang sudah diketahui beratnya, sambil dicuci dengan larutan $\mathrm{K}_{2} \mathrm{SO}_{4} 10 \%$.Cuci lagi residu dengan aquadest mendidih dan kemudian dengan lebih kurang $15 \mathrm{ml}$ alkohol 95\%.Bahan dikeringkan dengan kertas saring atau krus dengan isinya pada $110^{\circ} \mathrm{Csampai}$ berat konstan (1-2 jam), dinginkan dalam desikator dan timbang. Berat residu sama dengan berat serat kasar.

\section{Analisis Kadar Gula}

Untuk pengujian dengan metode hand refractometer (Sulaeman, 1994) dapat dilakukan sebagai berikut: bahan ditimbang 1 gram, kemudian bahan diencerkan dengan menggunakan aquades sebanyak $10 \mathrm{ml}$, kemudian dihomogenkan dengan spatula. Setelah itu diambil larutan dengan pipet tetes dan diteteskan pada kaca prisma refractometer, kemudian ditutup kaca dengan kemiringan $45^{\circ}$, diamati kearah sumber cahaya, setelah dicatat hasilnya.

\section{Analisis Derajat Keasaman (pH)}

Nilai pH diukur dengan menggunakan metode AOAC (2000).Sampel ditimbang sebanyak 5 gram dan dimasukkan ke dalam $10 \mathrm{ml}$ aquades, dikocok sampai homogen.Sebelum digunakan, $\mathrm{pH}$ meter dinyalakan, dibiarkan stabil selama 15-30 menit dan distandarisasi dengan buffer fosfat pH 4 dan pH 7. Elektroda dibilas dengan aquades dan dikeringkan dengan kertas tisu. Setelah elektrode dicelupkan kedalam sampel, pengukuran $\mathrm{pH}$ diset.Electrode dibiarkan tercelup beberapa saat sampai diperoleh pembacaan yang stabil.

\section{Uji Organoleptik}

Uji organoleptik yang diamati adalah, rasa, aroma,tekstur dan penerimaan keseluruhan dari dodol labu siam, pada penelitian ini digunakan uji hedonik atau uji tingkat kesukaan (Soekarto, 1985).Di dalam uji hedonik panelis diminta tanggapan secara langsung tentang tingkat kesukaannya. Tingkat kesukaan ini disebut dengan skala hedonik seperti: sangat suka, suka, agak suka, netral, agak tidak suka, sangat tidak suka. Dalam penganalisaannya skala hedonik ditransformasikan ke dalam skala numerik dengan angka tertentu dan kemudian dianalisis statistik. Pada tabel di bawah ini akan menjelaskan skala yang digunakan dalam pengujian organoleptik pada penelitian ini. 
Tabel 1

Uji Kesukaan Terhadap Tekstur Dodol Labu Siam

\begin{tabular}{|l|l|}
\hline \multicolumn{1}{|c|}{ Skala Hedonik } & Skala Numerik \\
\hline Kenyal, elastis, tidak mudah patah & 5 \\
\hline Kenyal, elastis, mudah patah & 4 \\
\hline Agak kenyal, elastis, tidak mudah patah & 3 \\
\hline Agak kenyak, elastis, mudah patah & 2 \\
\hline Tidak Kenyal, tidak elastis, tidak mudah patah & 1 \\
\hline
\end{tabular}

Tabel 2

Uji Kesukaan Terhadap Rasa Dodol Labu Siam

\begin{tabular}{|c|c|}
\hline Skala Hedonik & Skala Numerik \\
\hline Manis Legit & 5 \\
\hline Cukup Manis & 4 \\
\hline Agak Manis & 3 \\
\hline Kurang Manis & 2 \\
\hline Tidak Manis & 1 \\
\hline
\end{tabular}

Tabel 3

Uji Kesukaan Terhadap Aroma Dodol Labu Siam

\begin{tabular}{|c|c|}
\hline Skala Hedonik & Skala Numerik \\
\hline Sangat khas dodol labu siam & 5 \\
\hline Khas dodol labu siam & 4 \\
\hline Agak khas dodol labu siam & 3 \\
\hline Kurang khas dodol labu siam & 2 \\
\hline Tidak khas dodol labu siam & 1 \\
\hline
\end{tabular}

Tabel 4.

Uji Penerimaan Keseluruhan

\begin{tabular}{|c|c|}
\hline Skala Hedonik & Skala Numerik \\
\hline Sangat suka & 7 \\
\hline Suka & 6 \\
\hline Agak Suka & 5 \\
\hline Netral & 4 \\
\hline Agak tidak suka & 3 \\
\hline Tidak suka & 2 \\
\hline Sangat tidak suka & 1 \\
\hline
\end{tabular}

\subsection{Analisa Statistik}

Data yang diperoleh dari hasil penelitian akan dianalisa dengan metode analisis ragam. Untuk data obyektif apabila dalam analisa ragam didapatkan pengaruh perlakuan yang nyata atau sangat nyatadilanjutkan dengan uji Beda Nyata Terkecil (BNT) untuk mengetahui pasangan yang berbeda, sedangkan untuk data subyektif dilakukan uji Duncant (Hanafiah, 1994).

\section{Hasil dan Pembahasan}

Dari hasil penelitian yang dilakukan maka dapat dibahas beberapa hal, antara lain hasil analisis obyektif dan hasil analisis subyektif. Hasil penelitian obyektif terdiri dari analisis kadar air, kadar abu, kadar serat kasar, $\mathrm{pH}$, dan total gula sedangkan hasil penelitian subyektif yaitu meliputi penilaian secara 
organoleptik terhadap mutu dodol labu siam antara lain rasa, aroma, tekstur dan penerimaan secara keseluruhan.

\subsection{Variabel Obyektif}

Variabel obyektif terdiri dari analisis kadar air, kadar abu, kadar serat kasar, $\mathrm{pH}$, dan total gula. Nilai rata-rata hasil analisis pada dodol labu siam dapat dilihat pada Tabel 5.

Tabel 5

Nilai Rata-rata Kadar Air, Kadar Abu, Kadar Serat Kasar, pH, dan Kadar Gula Dodol Labu Siam pada Masing-masing Perlakuan

\begin{tabular}{llllll}
\hline Perlakuan & $\begin{array}{l}\text { Nilai rata- } \\
\text { rata Kadar } \\
\text { Air (\%) }\end{array}$ & $\begin{array}{l}\text { Nilai rata- } \\
\text { rata Kadar } \\
\text { Abu (\%) }\end{array}$ & $\begin{array}{l}\text { Nilai rata-rata } \\
\text { Kadar Serat } \\
\text { Kasar (\%) }\end{array}$ & $\begin{array}{l}\text { Nilai rata-rata } \\
\text { pH }\end{array}$ & $\begin{array}{l}\text { Nilai rata-rata } \\
\text { kadar gula } \\
(\% \text { brix) }\end{array}$ \\
\hline$(100 \%: 0 \%)$ & $16.428 \mathrm{a}$ & $0.545 \mathrm{a}$ & $0,765 \mathrm{a}$ & $6,798 \mathrm{a}$ & $15,167 \mathrm{a}$ \\
$(80 \%: 20 \%)$ & $18.054 \mathrm{a}$ & $0.707 \mathrm{a}$ & $0,882 \mathrm{a}$ & $6,570 \mathrm{a}$ & $14,797 \mathrm{~b}$ \\
$(70 \%: 30 \%)$ & $19.774 \mathrm{a}$ & $0.763 \mathrm{ab}$ & $0,925 \mathrm{~b}$ & $6,270 \mathrm{~b}$ & $14,660 \mathrm{~b}$ \\
$(60 \%: 40 \%)$ & $20,463 \mathrm{a}$ & $0.802 \mathrm{bc}$ & $1,007 \mathrm{c}$ & $6,018 \mathrm{c}$ & $14,348 \mathrm{~b}$ \\
$(50 \%: 50 \%)$ & $23.890 \mathrm{~b}$ & $0.891 \mathrm{bc}$ & $1,113 \mathrm{~d}$ & $5,731 \mathrm{~d}$ & $13,717 \mathrm{c}$ \\
$(40 \%: 60 \%)$ & $29,665 \mathrm{~b}$ & $1.027 \mathrm{c}$ & $1,515 \mathrm{e}$ & $5,660 \mathrm{e}$ & $13,255 \mathrm{c}$ \\
\hline
\end{tabular}

Keterangan : - Huruf yang berbeda di samping nilai rata-rata pada kolom yang sama menunjukkan perbedaan yang sangat nyata $(\mathrm{P}<0.05)$.

\section{Kadar Air}

Berdasarkan hasil sidik ragam, menunjukkan bahwa perlakuan konsentrasi tepung beras ketan dan labu siam berpengaruh sangat nyata (Fhit $=7,21 ; \mathrm{F}=>0,05$ ) terhadap kadar air dodol labu siam yang dihasilkan. Nilai rata-rata kadar air pada dodol labu siam dapat dilihat pada Tabel 5. Berdasarkan Tabel 5 diatas dapat dilihat bahwa kadar air yang dimiliki dodol labu siam berkisar antara 18,054\% - 29,665\%. Dari hasil penelitian ini, perlakuan $80 \%$ tepung ketan: $20 \%$ labu siammemiliki kadar air yang paling rendah yaitu $18,054 \%$, sedangkan kadar air tertinggi adalah pada perlakuan $40 \%$ tepung ketan: $60 \%$ labu siam yaitu sebesar 29,665\%. Badan Standar Nasional Indonesia (BSNI) mempersyaratkan maksimal kadar air pada dodol adalah 20\%. Meskipun demikian, Anonim (2009) menyebutkan bahwa kadar air dodol bervariasi antara $10-40 \%$, teksturnya bersifat lembek sampai padat, dan mempunyai kekenyalan yang berbeda. Dodol labu siam yang memenuhi SNI dalam penelitian ini adalah dodol labu siam dengan perlakuan 100\% tepung ketan: 0\% labu siam (kontrol), 80\% tepung ketan: 20\% labu siam, dan 70\% tepung ketan: 30\% labu siam.

Kadar air dodol dipengaruhi oleh bahan baku yang digunakan, suhu dan lama pemasakan pada dodol tersebut. Pada pembuatan dodol labu siam, pemasakan dodol masih kurang lama sehingga kandungan air dodol belum teruapkan. Untuk mendapatkan dodol dengan kriteria sampai kental dan tidak lengket di pengaduk merupakan prosedur yang cukup kritis, diperlukan kepekaan dan latihan sehingga diperoleh dodol dengan kekentalan yang pas, tidak keras dan tidak lembek. Dijelaskan bahwa untuk membuat dodol yang bermutu tinggi cukup sulit, karena proses pembuatannya yang lama, dan membutuhkan keahlian (Anonim, 2009).

\section{Kadar Abu}

Berdasarkan hasil sidik ragam menunjukkan bahwa perlakuan konsentrasi tepung beras ketan dan labu siam berpengaruh sangat nyata (Fhit $=9,553 ; \mathrm{p}=0,0014)$ terhadap kadar abu dodol labu siam yang 
dihasilkan. Nilai rata-rata kadar abu pada dodol labu siam dapat dilihat pada Tabel 5.

Berdasarkan Tabel 5 dapat dilihat bahwa kadar abu yang dimiliki dodol labu siam berkisar antara 0,707\%-1,027\%. Dari hasil penelitian ini, 80\% tepung ketan: 20\% labu siam memiliki kandungan kadar abu terendah yaitu $0,707 \%$, sedangkan $40 \%$ tepung ketan: $60 \%$ labu siam memiliki kandungan kadar abu tertinggi yaitu $1,027 \%$. Hal ini menunjukkan bahwa dodol labu siam yang dihasilkan berada dalam kisaran kadar abu menurut SNI, dimana kadar abu maksimum menurut SNI adalah 1,5\%.

Kadar abu merupakan campuran dari komponen anorganik atau mineral yang terdapat pada suatu bahan pangan. Bahan pangan terdiri dari $96 \%$ bahan anorganik dan air, sedangkan sisanya merupakan unsur-unsur mineral. Kadar abu dapat menunjukkan total mineral dalam suatu bahan pangan. Bahanbahan organik dalam proses pembakaran akan terbakar tetapi komponen anorganiknya tidak, karena itulah disebut sebagai kadar abu.

\section{Kadar Serat Kasar}

Berdasarkan hasil sidik ragam menunjukkan bahwa perlakuan konsentrasi tepung beras ketan dan labu siam berpengaruh nyata (Fhit $=186,99 ; p=1,536)$ terhadap kadar serat kasar dodol labu siam yang dihasilkan. Rata-rata kadar serat kasar pada dodol labu siam dapat dilihat pada Tabel 5. Berdasarkan Tabel 5 dapat dilihat bahwa kadar serat kasar yang dimiliki dodol labu siam berkisar antara 0,882\%1,515\%. Dari data di atas diketahui bahwa 80\% tepung ketan: 20\% labu siam memiliki kandungan kadar serat kasar terendah yaitu 0,88\%, sedangkan 40\% tepung ketan: $60 \%$ labu siam memiliki kandungan kadar serat kasar tertinggi yaitu $1.515 \%$. Semakin tinggi penambahan labu siam, maka semakin tinggi pula kadar serat kasar yang dihasilkan. Hal tersebut dikarenakan labu siam mengandung kadar serat kasar yang cukup tinggi yaitu 1,7 gram per 100 gram. Kadar serat yang dihasilkan dodol labu siam memenuhi SNI dimana standar kadar serat kasar yaitu maksimal 1-2,5\%.

\section{Derajat Keasaman (pH)}

Hasil analisa sidik ragam menunjukkan bahwa perlakuan konsentrasi tepung beras ketan dan labu siam berpengaruh nyata (Fhit $=228,36 ; \mathrm{p}=5,72)$ terhadap $\mathrm{pH}$ dodol labu siam yang dihasilkan. Nilai rata-rata kandungan $\mathrm{pH}$ pada dodol labu siamdapat dilihat pada Tabel 5. Berdasarkan Tabel 5 dapat dilihat bahwa rata-rata derajat keasaman $(\mathrm{pH})$ yang dimiliki dodol labu siam berkisar antara 5,660\%6,798\%. Dari data di atas diketahui bahwa 40\% tepung ketan: $60 \%$ labu siam memiliki pH terendah yaitu 5,660 sedangkan $80 \%$ tepung ketan: $20 \%$ labu siam memiliki $\mathrm{pH}$ tertinggi yaitu 6,570. Semakin banyak penambahan labu siam pada pembuatan dodol labu siam, maka $\mathrm{pH}$ yang dihasilkan akan semakin rendah.

\section{Kadar Gula}

Hasil analisa sidik ragam menunjukkan bahwa perlakuan konsentrasi tepung beras ketan dan labu siam berpengaruh nyata (Fhit $=104,41 ; \mathrm{p}=2,68$ ) terhadap total gula dodol labu siam yang dihasilkan. Nilai rata-rata kandungan total gula pada dodol labu siam dapat dilihat pada Tabel 5. Berdasarkan Tabel diatas dapat dilihat bahwa nilai rata-rata kadar gula dodol labu siam berkisar antara 13,255\% brix$14.797 \%$ brix. Dari data di atas diketahui bahwa 40\% tepung ketan: 60\% labu siam memiliki kandungan kadar gula terendah yaitu $13,255 \%$ brix, sedangkan $80 \%$ tepung ketan: $20 \%$ labu siam memiliki 
kandungan total gula tertinggi yaitu $14,797 \%$ brix. Hal ini di sebabkan karena perbedaan kandungan gula pada labu siam dengan tepung ketan, dimana labu siam mengandung gula yang lebih sedikit dibandingkan tepung ketan, sehingga semakin banyak penambahan labu siam pada pembuatan dodol labu siam, maka kandungan gula dodol labu siam tersebut semakin rendah. Pada penelitian ini didapatkan kadar gula pada masing-masing sampel lebih rendah dibandingkan dengan standar kadar gula menurut SNI yaitu minimal $35-45 \% \mathrm{~b} / \mathrm{b}$ dikarenakan skala ${ }^{\circ}$ Brix dari refraktometer sama dengan berat gram sukrosa dari $100 \mathrm{~g}$ larutan sukrosa.

\subsection{Variabel Subyektif}

Variabel subyektif dianalisa dengan Uji Sensoris yang meliputi tekstur, aroma, rasa dan penerimaan keseluruhan dodol labu siam. Nilai rata-rata uji sensoris pada dodol labu siam dapat dilihat pada Tabel 6 .

Tabel 6.

Nilai Rata-rata Uji Sensoris Dodol Labu Siam pada Masing-masing Perlakuan

\begin{tabular}{lllll}
\hline Perlakuan & Tekstur & Aroma & Rasa & Penerimaan Keseluruhan \\
\hline$(100 \%: 0 \%)$ & $4,762 \mathrm{a}$ & $1,000 \mathrm{a}$ & $4,476 \mathrm{a}$ & $6,429 \mathrm{a}$ \\
$(80 \%: 20 \%)$ & $4,524 \mathrm{a}$ & $1,857 \mathrm{~b}$ & $4,429 \mathrm{a}$ & $6,238 \mathrm{a}$ \\
$(70 \%: 30 \%)$ & $4,286 \mathrm{~b}$ & $3,000 \mathrm{c}$ & $4,286 \mathrm{~b}$ & $5,714 \mathrm{~b}$ \\
$(60 \%: 40 \%)$ & $3.857 \mathrm{~b}$ & $3,143 \mathrm{c}$ & $4,238 \mathrm{~b}$ & $5,429 \mathrm{~b}$ \\
$(50 \%: 50 \%)$ & $3,238 \mathrm{c}$ & $3,429 \mathrm{c}$ & $3,714 \mathrm{c}$ & $4,571 \mathrm{c}$ \\
$(40 \%: 60 \%)$ & $2,714 \mathrm{c}$ & $3,952 \mathrm{~d}$ & $3,571 \mathrm{c}$ & $4,333 \mathrm{c}$ \\
\hline
\end{tabular}

\section{Tekstur}

Berdasarkan hasil analisis ragam yang dilakukan terhadap tekstur dodol labu siam, didapatkan bahwa perlakuan perbandingan jumlah tepung ketan dan labu siam menunjukkan pengaruh yangsangat nyata $(\mathrm{P}<0,05)$ terhadap tekstur dodol labu siam yang dihasilkan. Nilai rata-rata uji skor terhadap teksturdapat dilihat pada Tabel 6. Penilaian rata-rata panelis terhadap tekstur dodol labu siam (Tabel 6) berkisar antara 2,714 sampai 4,524 (agak kenyal, elastis, mudah patah sampai kenyal, elastis, tidak mudah patah). Penilaian panelis tertinggi terhadap tekstur dodol labu siam diperoleh pada perlakuan 80\% tepung ketan: $20 \%$ labu siam yaitu 4,524 (kenyal, elastis, tidak mudah patah), sedangkan penilaian panelis terendah diperoleh pada perlakuan $40 \%$ tepung ketan: $60 \%$ labu siam yaitu 2,714 (agak kenyal, elastis, mudah patah).

\section{Aroma}

Berdasarkan hasil analisis ragam yang dilakukan terhadap aroma dodol labu siam, didapatkan bahwa perlakuan perbandingan jumlah tepung ketan dan labu siam menunjukkan pengaruh yang sangat nyata $(\mathrm{P}<0,05)$ terhadap aroma dodol labu siam. Nilai rata-rata uji hedonik terhadap aroma dapat dilihat pada Tabel 6. Penilaian rata-rata panelis terhadap aroma dodol labu siam (Tabel 6) berkisar antara 1,857 sampai 3,952 (tidak khas dodol labu siam sampai khas dodol labu siam). Penilaian panelis tertinggi terhadap aroma dodol labu siam diperoleh pada perlakuan 40\% tepung ketan: $60 \%$ dodol labu siam yaitu 3,952 (khas dodol labu siam), sedangkan penilaian panelis terendah diperoleh pada perlakuan $80 \%$ tepung ketan: 20\% labu siam yaitu 1,857 (tidak khas dodol labu siam). Hal ini kemungkinan disebabkan karena semakin banyak penambahan labu siam, maka aroma dodol labu siam tersebut akan semakin khas. 


\section{Rasa}

Berdasarkan hasil analisis ragam yang dilakukan terhadap rasa dodol labu siam, didapatkan bahwa perlakuan perbandingan jumlah tepung ketan dan labu siam menunjukkan pengaruh yang sangat nyata $(\mathrm{P}<0,05)$ terhadap rasa. Nilai rata-rata uji hedonik terhadap rasa dapat dilihat pada Tabel 6. Penilaian rata-rata panelis terhadap rasa dodol labu siam (Tabel 6) berkisar antara 3.571 sampai 4,429 (agak manis sampai manis legit). Penilaian panelis tertinggi terhadap rasa dodol labu siam diperoleh pada perlakuan 80\% tepung ketan: 20\% labu siam yaitu 4,429 (manis legit), sedangkan penilaian panelis terendah diperoleh pada perlakuan 40\% tepung ketan: 60\% labu siam yaitu 3,571 (cukup manis). Hal ini disebabkan karena kadar gula pada labu siam lebih rendah dibandingkan total gula pada tepung ketan.

\section{Penerimaan Keseluruhan}

Berdasarkan hasil analisis ragam yang dilakukan terhadap penerimaan keseluruhan dodol labu siam, didapatkan bahwa perlakuan perbandingan jumlah tepung ketan dan labu siam menunjukkan pengaruh yang sangat nyata $(\mathrm{P}<0,05)$ terhadap rasa dodol labu siam. Nilai rata-rata uji hedonik terhadap penerimaan keseluruhan dapat dilihat pada Tabel 6. Penilaian rata-rata panelis terhadap penerimaan keseluruhan dodol labu siam berkisar antara 4,333 sampai 6,238 (cukup suka sampai sangat suka). Penilaian panelis tertinggi terhadap penerimaan keseluruhan dodol labu siam diperoleh pada perlakuan 80\% tepung ketan: 20\% labu siam yaitu 6,238 (amat sangat suka), sedangkan penilaian panelis terendah diperoleh pada perlakuan 40\% tepung ketan: 60\% labu siam yaitu 4,333 (cukup suka). Hal ini kemungkinan disebabkan karena panelis belum terbiasa mengkonsumsi dodol labu siam sehingga semakin banyak penambahan labu siam pada pembuatan dodol labu siam, maka tingkat kesukaaan panelis terhadap penerimaan keseuruhan semakin rendah.

\section{Kesimpulan}

Perbandingan tepung ketan dan labu siam berpengaruh nyata terhadap kadar air, kadar abu, kadar serat kasar, $\mathrm{pH}$, total gula, tekstur, aroma, rasa, dan penerimaan keseluruhan. Perbandingan tepung ketan $70 \%$ dan labu siam 30\% mengasilkan dodol labu siam yang baik dan tidak berbeda nyata dengan kontrol (100\% tepung ketan: 0\% labu siam). Adapun karakteristik dodol labu siam yang dihasilkan dari perlakuan perbandingan $70 \%$ tepung ketan: $30 \%$ labu siam adalah kadar air $19.774 \%$, kadar abu $0.763 \%$, kadar serat kasar $0.925 \%$, pH 6.270, total gula 14.6600 brix, tekstur 4.286 (kenyal, elastis, tidak mudah patah), aroma 3.000 (agak khas dodol labu siam), rasa 4.286 (manis legit), dengan penerimaan keseluruhan 5.714 (suka).

Berdasarkan hasil penelitian ini disarankan untuk melanjutkan pengujian terhadap masa simpan dan pengemasan dodol labu siam. Untuk mendapatkan karakteristik yang baik dalam pembuatan dodol labu siam disarankan menggunakan perbandingan 70\% tepung ketan dan 30\% labu siam.

\section{Referensi}

Anonim (2009). Dodol dari labu siam. http.sinartani.com/pascapanen/dodol-bahan-labusiam.6 mei 2009.

AOAC. (1990). Official Methods of Analisis. Asosiaion of Official Analitic Chemist. Washington DC. USA

Hanafiah, K.A. (1993). Rancangan Percobaan Teori dan Aplikasi. Jakarta :Rajawali Pers 
Perbandingan Tepung Ketan dan Labu Siam (Sechium Edule) Terhadap Karakteristik Dodol

Modgil, M., Modgil, R., \& Kuma, R. (2004). Carbohydrate and Mineral Content of Chyote (Sechium edule) and Bottle Gourd (Lagenaria Siceraria). Hum Ecol. 15(2): 157-159.

Prayitno, S. (2002). Aneka Olahan Dodol. Yogyakarta : Kanisius.

Saade, R. L. (1996). Chayote. Sechium edule (Jacq.) Sw. International Plant Genetic Resources Institute, 8-46.

Soekarto (1985). Penilaian Organoleptik Untuk Industri Pangan dan Hasil Pertanian.Jakarta: Bhatara Aksara.

Sudarmadji, S., Haryono, B., \& Suhardi (1984). Prosedur Analisa untuk Bahan Makanan dan Pertanian. Liberty, Yogyakarta.

Sudarmadji, S., Haryono, B., \& Suhardi (1996). Analisa Bahan Makanan dan Pertanian. Yogyakarta: Penerbit Liberty.

Sudarmadji S., Haryono,B., dan Suhardi (1997). Prosedur Analisa untuk Bahan Makanan dan Pertanian. Liberty. Yogyakarta.

Sulaeman, A., F. Anwar, Rimbawan, S.A. Marliyati (1994). Metode Penetapan Zat Gizi. Jurusan Gizi Masyarakat dan Sumberdaya Keluarga, Fakultas Pertanian IPB, Bogor. 